\title{
First Report of Rhizopus oryzae as a Postharvest Pathogen of Apple in Korea
}

\author{
Jin-Hyeuk Kwon ${ }^{1 *}$, Jinwoo Kim ${ }^{2}$ and Won-Il Kim ${ }^{3}$ \\ ${ }^{\prime}$ Gyeongsangnam-do Agricultural Research and Extension Services, Jinju 660-360, Korea \\ ${ }^{2}$ Institute of Agriculture and Life Science, Gyeongsang National University, Jinju 660-701, Korea \\ ${ }^{3}$ National Academy of Agricultural Science, Rural Development Administration, Suwon 441-707, Korea
}

(Received January 24, 2011. Accepted May 13, 2011)

Soft rot in apple caused by Rhizopus oryzae was found for the first time in Korea. A detailed description of the specimen is given along with its internal transcribed spacer rDNA sequence. The fungus was identified as Rhizopus oryzae based on the mycological characteristics, molecular data, and pathogenicity testing.

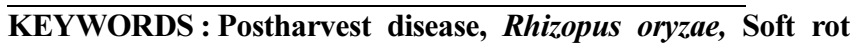

Postharvest diseases including soft rot occur on the succulent tissues of vegetables, fruits, and ornamental plants worldwide. Postharvest losses as a result of fungal infection occur if products are stored at the incorrect temperature, stored for an extended period of time at cold temperatures, or as a result of mechanical failure during storage or transport [1]. In March 2010, a disease suspected to be Rhizopus soft rot was observed on apple fruit at commercial markets in Jinju, Korea.

Symptoms. The first symptom of soft rot on apple fruit was a water-soaked appearance to the affected tissue. The diseased parts later disintegrated into a mushy mass of disorganized cells that sloughed off. Rapid softening and disintegration of the diseased tissue followed. White mycelia formed on infection sites of apples and gradually covered the fruit with tufted whisker-like gray sporangiophores and sporangia (Fig. 1A). Longitudinal sections of the infected apple fruit appeared softened and severely rotted (Fig. 1B).

Mycological characteristics. The causal fungus was isolated from the diseased fruit sampled from commercial markets. Sporangiospores, sporangia, and sporangiophores were observed under a light microscope (Table 1) [2]. The fungal colonies that grew on potato dextrose agar were initially white and cottony, then became heavily speckled with sporangia, and finally became brownish-grey to blackish-grey and spread rapidly with stolons fired at various points to the substrate by rhizoids (Fig. 2A). The optimum temperature for mycelial growth was $30^{\circ} \mathrm{C}$, with good growth still apparent at $37^{\circ} \mathrm{C}$. Sporangiospores were unequal, numerous, irregular, sub-globose or oval, angular with striations, and $4 \sim 8 \mu \mathrm{m}$ (Fig. $2 \mathrm{~B}$ ). Sporangiophores were usually straight, mostly $8 \sim 20 \mu \mathrm{m}$, smooth-walled, simple or branched, non-septate, long, and arose from stolons opposite rhizoids usually in groups of 3 5 or more. Sporangia were globose, white at first, and then turned black with many spores, mostly 40 200 $\mu \mathrm{m}$ (Fig. 2C). Columella were globose to sub-globose, pale brown, and mostly $85 \sim 110 \mu \mathrm{m}$ (Fig. 2D). Rhizoids and stolons were dark brown (Fig. 2E).

Pathogenicity testing. Twelve apple fruits were artificially inoculated with a representative fungus using the wound infection method. A conidial suspension $(0.1 \mathrm{~mL}$; $3 \times 10^{4}$ conidia $/ \mathrm{mL}$ ) of the causal fungus was placed on the surface of apple fruit. The inoculated fruit was kept in a moist chamber with $100 \%$ relative humidity at $30^{\circ} \mathrm{C}$. After a 3 day incubation, the same fungal symptoms were reproduced: soft rot was observed on inoculated fruits that was identical to symptoms observed at the commercial markets (Fig. 1C and 1D). The causal pathogen was reisolated from the lesions to prove Koch's postulates.

Internal transcribed spacer (ITS) sequence analysis. To confirm the identity of the causal fungus, the ITS rDNA of the isolate was amplified and sequenced using ITS1 (5'-TCCGTAGGTGAACCTGCGG-3') and ITS4 primers (5'-TCCTCCGCTTATTGATATGC-3'), as described by White et al. [3]. The resulting 626-bp sequence was deposited in GenBank (accession No. HQ897687). A phy-

\footnotetext{
$\overline{\text { *Corresponding author }}<$ E-mail : kwon825@korea.kr>

@ This is an Open Access article distributed under the terms of the Creative Commons Attribution Non-Commercial License (http://creativecommons.org/licenses/by-nc/3.0/) which permits unrestricted non-commercial use, distribution, and reproduction in any medium, provided the original work is properly cited.
} 


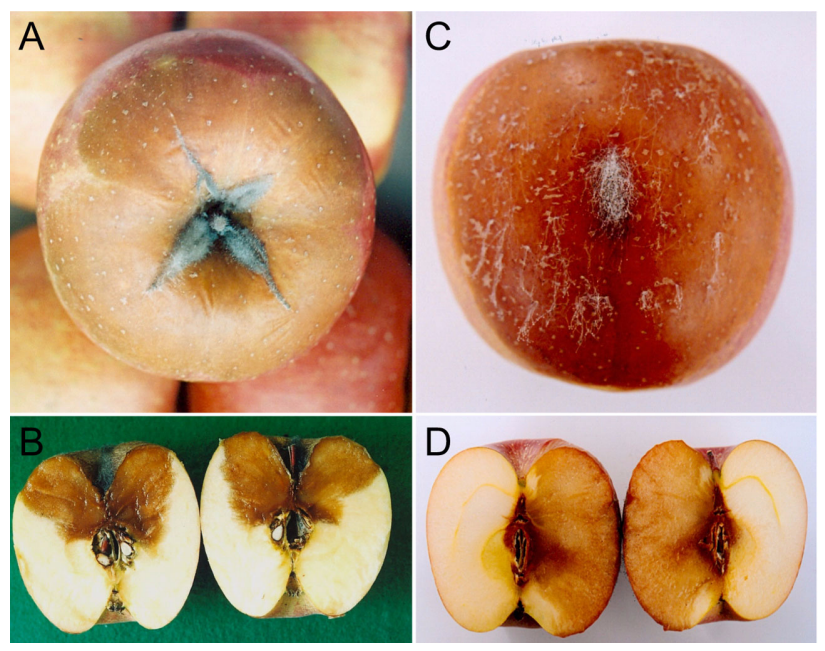

Fig. 1. Symptoms of soft rot on apple (Malus pumila var. dulcissima Koidz.) caused by Rhizopus oryzae. A, Soft rot symptoms on apple fruit sampled from commercial markets; B, Longitudinal section of apple. Symptoms were induced naturally; C, Symptoms induced by artificial inoculation; D, Longitudinal section of apple. Symptoms were induced artificially. logenetic analysis was performed using MEGA4 with the neighbor-joining method and the Tajima-Nei distance model.

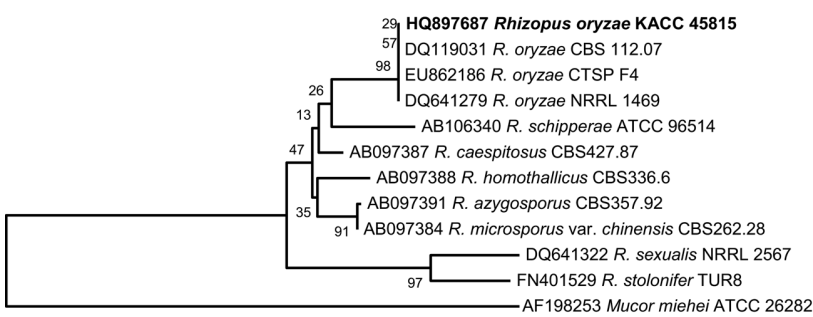

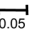

Fig. 3. Phylogenetic tree using internal transcribed spacer (ITS) sequences showing closest known relatives of Rhizopus oryzae, including soft rot fungus infecting Malus pumila var. dulcissima Koidz. DNA sequences from the NCBI nucleotide database were aligned using ClustalW, and a phylogenetic tree was constructed using the neighborjoining method and visualized with TreeView. Numbers above the branches indicate bootstrap values. Bars indicate number of nucleotide substitutions per site. The present isolate infecting $M$. pumila is marked in bold.

Table 1. Comparison of morphological characteristics of soft rot fungus isolated from apple (Malus pumila var. dulcissima Koidz.) with previous descriptions of Rhizopus oryzae

\begin{tabular}{llll}
\hline \hline Characteristics & & Isolate in present study & $R$. oryzae [2] \\
\hline Colony & Color & Brownish-grey to blackish-grey & Brownish-grey to blackish-grey \\
Sporangium & Shape & Globose & Globose \\
& Size & $40 \sim 200 \mu \mathrm{m}$ in diameter & $30 \sim 210 \mu \mathrm{m}$ in diameter \\
Sporangiospore & Shape & Sub-globose or oval & Sub-globose, limoniform \\
& Size & $4 \sim 8 \mu \mathrm{m}$ in length & $4 \sim 10 \mu \mathrm{m}$ in length \\
Sporangiophore & Size & $8 \sim 20 \mu \mathrm{m}$ in diameter & $7 \sim 20 \mu \mathrm{m}$ in diameter \\
Columellum & Shape & Globose to sub-globose & Globose to sub-globose \\
& Size & $85 \sim 110 \mu \mathrm{m}$ in diameter & $90 \sim 120 \mu \mathrm{m}$ in diameter \\
\hline
\end{tabular}
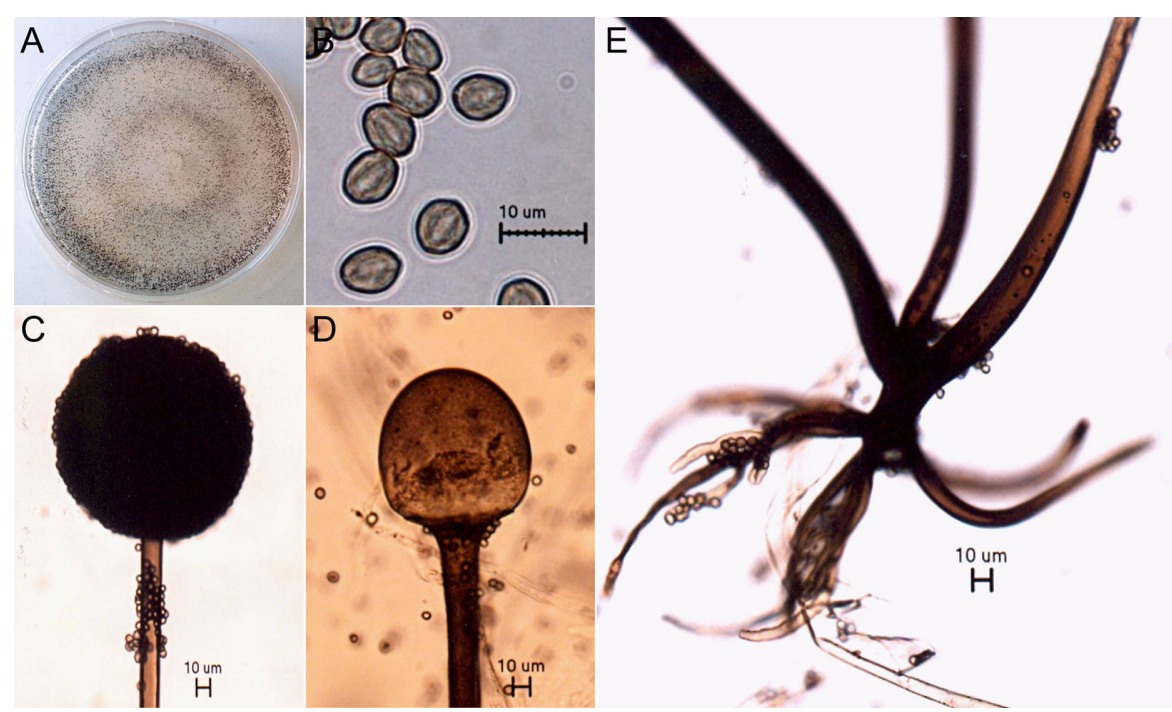

Fig. 2. Morphological characteristics of Rhizopus oryzae isolated from soft rot lesions on apple (Malus pumila var. dulcissima Koidz.). A, Colony on potato dextrose agar after a 7 day incubation; B, Sporangium and sporangiophore; C, Columella; D, Sporangiospores; E, Rhizoids. 
Previously published ITS sequences from $R$. oryzae strains were included for reference, and Mucor miehei (GenBank accession No. AF198253) was used as an out-group [4]. In the phylogenetic tree, the present isolate was placed within a clade comprising $R$. oryzae references isolates (Fig. 3).

Soft rot of apple caused by $R$. stolonifer has been reported previously [5], but soft rot caused by $R$. oryzae has not been recorded in Korea [6]. The representative culture of the causal fungus was deposited in the Korean Agricultural Culture Collection (KACC 45815), National Academy of Agricultural Science, Suwon, Korea. Based on the mycological characters, molecular data, and pathogenicity testing of the host plant, the fungus was identified as Rhizopus oryzae Went \& Prisen Geerligs [2]. This is the first report of $R$. oryzae on apple in Korea.

\section{Acknowledgements}

This work was conducted with the support of the Cooperative Research Program for Agriculture Science \& Technology Development (PJ007345), Rural Development Administration, Korea.

\section{References}

1. Agrios GN. Plant pathology. 5th ed. New York: Academic Press; 2005.

2. Lunn JA. Rhizopus oryzae. CMI descriptions of pathogenic fungi and bacteria. No. 525. Kew: Commonwealth Mycological Institute; 1977.

3. White TJ, Bruns T, Lee S, Taylor JW. Amplification and direct sequencing of fungal ribosomal RNA genes for phylogenetics. In: Innis MA, Gelfand DH, Sninsky JJ, White TJ, editors. PCR protocols: a guide to methods and applications. New York: Academic Press; 1990. p. 315-22.

4. Abe A, Oda Y, Asano K, Sone T. The molecular phylogeny of the genus Rhizopus based on rDNA sequences. Biosci Biotechnol Biochem 2006;70:2387-93.

5. Kwon JH, Jee HJ. Occurrence of rhizopus soft rot on apple fruit caused by Rhizopus stolonifer in Korea. Res Plant Dis 2008;14:57-60.

6. Korean Society of Plant Pathology. List of plant diseases in Korea. 5th ed. Seoul: Korean Society of Plant Pathology; 2009. 